\title{
Task Force 1. Report of the Task Force on Patient Expectations, Core Values, Reintegration, and the New Model of Family Medicine
}

\author{
Task Force 1 Writing Group* \\ Larry A. Green, $M D^{1}$ \\ Robert Grabam, $M D^{2}$ \\ Bruce Bagley, $M D^{3}$ \\ Charles M. Kilo, MD, MPH \\ Stephen J. Spann, MD \\ Stephen P. Bogdewic, $P b D^{6}$ \\ Jobn Swanson, MPH \\ ${ }^{\prime}$ Chair, Task Force 1, Co-Editor Task Force \\ 1 Report, Denver, Colo, and Washington, DC \\ ${ }^{2}$ Co-Editor, Task Force 1 Report, Bethesda, Md \\ ${ }^{3}$ Chair, Core Values Writing Group, Task \\ Force 1, Leawood, Kan
}

${ }^{4}$ Chair, Patient Expectations Writing Group Task Force 1, Portland, Ore

${ }^{5}$ Chair, New Model Writing Group, Task Force 1, Houston, Tex

${ }^{6}$ Chair, Essential Interfaces and Reintegration with Patients Writing Group; Vice Chair,

Task Force 1, Indianapolis, Ind

${ }^{7}$ Staff Executive, American Academy of

Family Physicians, Leawood, Kan

*See Acknowledgments for a complete list of Task Force 1 members.

Conflicts of interest: none reported

\section{CORRESPONDING AUTHOR}

John Swanson, MPH

American Academy of Family Physicians

11400 Tomahawk Creek Parkway

Leawood, KS 66211-2672

jswanson@aafp.org

\begin{abstract}
BACKGROUND To lay the groundwork for the development of a comprehensive strategy to transform and renew the specialty of family medicine, this Future of Family Medicine task force was charged with identifying the core values of family medicine, developing proposals to reform family medicine to meet consumer expectations, and determining systems of care to be delivered by family medicine in the future.
\end{abstract}

METHODS A diverse, multidisciplinary task force representing a broad spectrum of perspectives and expertise analyzed and discussed published literature; findings from surveys, interviews, and focus groups compiled by research firms contracted to the Future of Family Medicine project; and analyses from The Robert Graham Center, professional societies in the United States and abroad, and others. Through meetings, conference calls, and writing, and revision of a series of subcommittee reports, the entire task force reached consensus on its conclusions and recommendations. These were reviewed by an external panel of experts and revisions were made accordingly.

MAJOR FINDINGS After delivering on its promise to reverse the decline of general practice in the United States, family medicine and the nation face additional challenges to assure all people receive care that is safe, effective, patient-centered, timely, efficient, and equitable. Challenges the discipline needs to address to improve family physicians' ability to make important further contributions include developing a broader, more accurate understanding of the specialty among the public and other health professionals, addressing the wide scope and variance in practice types within family medicine, winning respect for the specialty in academic circles, making family medicine a more attractive career option, and dealing with the perception that family medicine is not solidly grounded in science and technology.

The task force set forth a proposed identity statement for family medicine, a basket of services that should be reliably provided in family medicine practices, and an itemization of key attributes and core values that define the specialty. It also proposed and described a New Model of family medicine for people of all ages and both genders that emphasizes patient-centered, evidence-based, whole-person care provided through a multidisciplinary team approach in settings that reduce barriers to access and use advanced information systems and other new technologies.

The task force recommended a time of active experimentation to redesign the work and workplace of family physicians; the development of revised financial models for family medicine, and a national resource to provide assistance to individual practices moving to New Model practice; and cooperation with others pursuing the transformation of frontline medicine to better serve the public.

CONCLUSIONS Unless there are changes in the broader health care system and within the specialty, the position of family medicine in the United States will be 
untenable in a 10- to 20-year time frame. Even within the constraints of today's flawed health care system, there are major opportunities for family physicians to realize improved results for patients and economic success. A period of aggressive experimentation and redevelopment of family medicine is needed now. The future success of the discipline and its impact on public well-being depends in large measure on family medicine's ability to rearticulate its vision and competencies in a fashion that has greater resonance with the public while substantially revising the organization and processes by which care is delivered. When accomplished, family physicians will achieve more fully the aspirations articulated by the specialty's core values and contribute to the solution of the nation's serious health care problems.

Ann Fam Med 2004;2:S33-S50. DOI: 10.1370/afm.134.

TASK FORCE CHARGE: Consider the core attributes and values of family medicine and propose ideas about reforming family medicine and primary care to meet the contemporary needs and expectations of the people of the United States.

\section{THE PROBLEM IN CONTEXT}

$\mathrm{B}$ y 2002 the specialty of family medicine had delivered on its promise to reverse the decline of general practice ${ }^{1,2}$ and provide personal, frontline medical care to people of all socioeconomic strata and in all regions of the United States. ${ }^{3}$ All was not well, however, either with family medicine or with health care in general. ${ }^{4-11}$

At the national level, serious health policy issues proved to be intractable. A large proportion of the population (at least 40 million people) lacked health insurance, ${ }^{12}$ almost $20 \%$ of the population lacked a usual source of care, ${ }^{13,14}$ the public health infrastructure remained weak, ${ }^{15,16}$ and mental health care struggled for recognition and parity. ${ }^{17}$ There was renewed uncertainty about the adequacy of the health care workforce, ${ }^{18-26}$ confirmation of important disparities in health and health care, ${ }^{27}$ alarm about medical errors in all health care settings, ${ }^{28,29}$ and concern about accelerating health care spending, with a return to doubledigit price escalation in health insurance premiums while the national economy slumped. ${ }^{30,31}$ Personal stories of despair and forecasts of collapse of the health care system were daily fare in the newspapers. ${ }^{32-34}$

Concern and frustration among family physicians with the direction of health care in the United States did not arise overnight. The 1990s began with a spirit of optimism that managed care would actually manage care and organize a fragmented and wasteful system, with family physicians and other primary care providers having a defined and central role. Soon this optimism gave way to great frustration when, instead of integration of care in the context of a sustained partnership between patients and their personal physicians, new layers of administrative decision makers - with arguably conflicting objectives-appeared. In this new, suddenly less positive, practice environment, family physicians found themselves painted as gatekeepers standing between their patients and care, rather than being able to serve their patients as gateways to appropriate care.

Trust eroded as relationships were fractured repeatedly by treating health care as a commodity that could be bought and sold, with large blocks of insured patients being moved annually from health plan to health plan, provider to provider, and system of care to system of care. The daily work at family medicine's front line became known as "hamster medicine," as physicians and their staffs worked harder and harder in a struggle to maintain their economic status. Few family physicians lacked for patients, but for many physicians work devolved from meaningful service grounded in rich, personal relationships, into jobs designed to manufacture health care that too often neither healed nor relieved suffering. ${ }^{35}$ While medical expenditures increased, net income for physicians declined, more so for primary care physicians than specialists. ${ }^{36}$

In 1996, the Institute of Medicine (IOM), through the Committee on the Future of Primary Care, concluded that the nation's understanding of primary care was so poor that it was necessary to redefine it in order to establish a basis for study. The IOM definition clarified that primary care is not a discipline or specialty but a function that is essential as the foundation of a successful, sustainable health care system. ${ }^{37}$ Although many types of providers laid claims to providing primary care, the IOM concluded that the evidence pointed to family physicians, general internists, general pediatricians, and many nurse practitioners and physician assistants as being the key primary care providers in the United States. That family physicians were key providers of primary care was indisputable; thus, family medicine and primary care were and remain intertwined. ${ }^{38}$

The 1996 IOM report on primary care was prepared at a time when universal coverage and health care reform on a national scale were anticipated. Such was not to be, however, and the report's call for investment in primary care went largely unheeded. In the years since the issuance of that IOM report, the rate of growth in the specialty physician pool has continued to far exceed the rate of growth in family medicine and other primary care specialties, which is reflected in the minimal growth in numbers of primary care physicians per 1,000 population compared with the growth experienced by specialists other than primary care physicians (Figure1). 


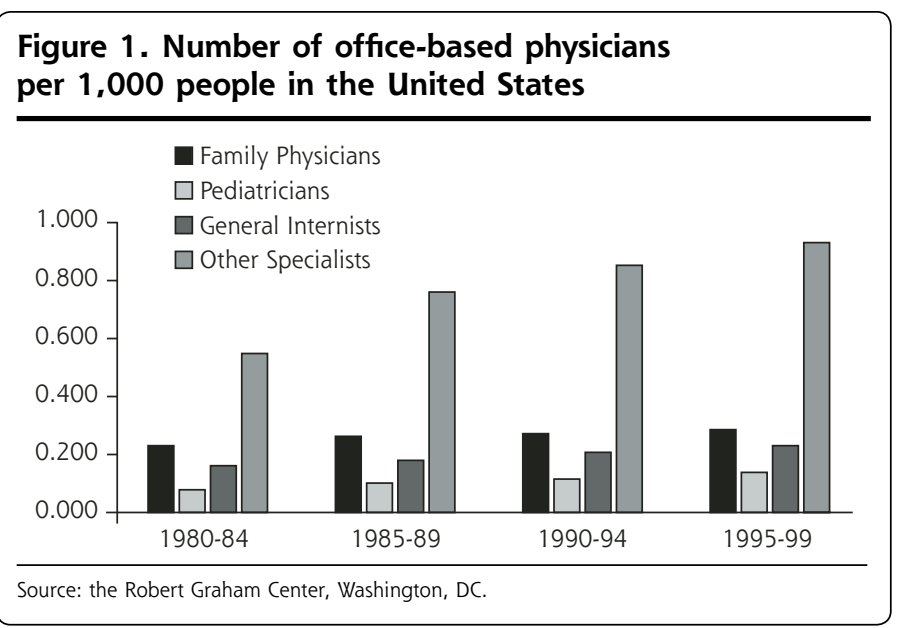

Meanwhile, interest expressed by medical students in family medicine declined, ${ }^{39}$ which was manifested by declining match rates into family medicine residency training programs (Figure 2).

As the 21 st century began, a sustained focus on the quality of health care in the United States by the IOM culminated in widely received publications that provided ominous warnings regarding the overall state of health care in the United States. ${ }^{28,40}$ The 2001 IOM report, Crossing the Quality Chasm: A New Health System for the 21st Century ${ }^{40}$ (the Chasm Report) made the startling assertion that the health care system of the United States was so flawed that it could not be fixed and required an overhaul. This landmark report articu- lated 6 aims for the 21 st century health care system (Table 1 ).

These aims were widely perceived to be valid and were embraced by many family physicians as being consistent with their purpose and their aspirations. The report went further and proposed rules that could guide the redesign of health care away from a decaying and failing system toward a new system of which the United States could be proud (Table 2). These rules were yet another call to action that was consistent with the goals and natural inclinations of family physicians and others committed to robust primary care for the nation.

With such a report prominently displayed on the national scene and with family physicians being such an important part of a flawed system, the importance of careful but definitive action became clear. A weak economy, huge deficits at the federal and state levels, growing numbers of uninsured persons, and health care expenditures once again on a steep rising curve united to create a sense of urgency that something needed to be done.

At the level of the discipline, family medicine was challenged by contradictions and tensions, including confusion about family medicine being a reform movement (a solution) or an incumbent medical specialty (a problem), questions regarding whether family physicians should be considered generalists or specialists, debate about family medicine being vital for all or an

\section{Figure 2. Positions offered and filled with US seniors in March 1992-2003.}

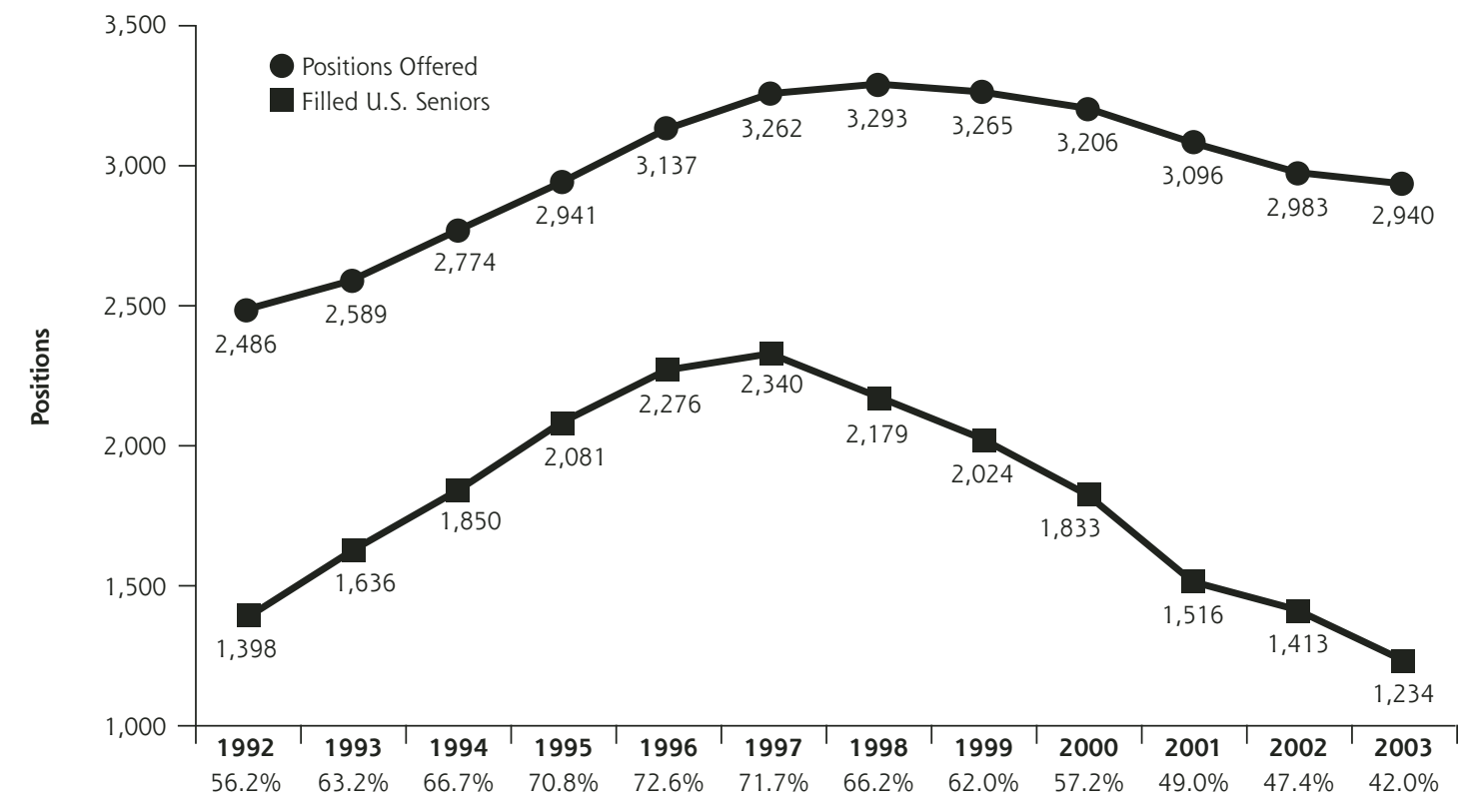

Source: American Academy of Family Physicians, Leawood, Kan. 


\section{Table 1. Six Aims for the 21st Century Health Care System}

Safe-Avoiding injuries to patients from the care that is intended to help them

Effective-Providing services based on scientific knowledge to all who could benefit and refraining from providing services to those not likely to benefit

Patient-centered-Providing care that is respectful of and responsive to individual patient preferences, needs, and values, and ensuring that patient values guide all clinical decisions

Timely-Reducing waits and sometimes harmful delays for both those who receive and those who give care

Efficient-Avoiding waste, including waste of equipment, supplies, ideas and energy

Equitable-Providing care that does not vary in quality because of personal characteristics such as gender, ethnicity, geographic location, and socioeconomic status

Source: Institute of Medicine. Crossing the Quality Chasm: A New Health System for the 21st Century. Washington, DC: National Academy Press, 2001.

\section{Table 2. Simple Rules for the 21 st Century Health Care System}

\begin{tabular}{|c|c|}
\hline Current Approach & New Rule \\
\hline Care is based primarily on visits & Care is based on continuous healing relationships \\
\hline Professional autonomy drives variability & $\begin{array}{l}\text { Care is customized according to patient needs and } \\
\text { values }\end{array}$ \\
\hline Professionals control care & The patient is the source of control \\
\hline Information is a record & Knowledge is shared and information flows freely \\
\hline $\begin{array}{l}\text { Decision making is based on training and } \\
\text { experience }\end{array}$ & Decision making is evidence-based \\
\hline Do no harm is an individual responsibility & Safety is a system property \\
\hline Secrecy is necessary & Transparency is necessary \\
\hline The system reacts to needs & Needs are anticipated \\
\hline Cost reduction is sought & Waste is continuously decreased \\
\hline $\begin{array}{l}\text { Preference is given to professional roles } \\
\text { rather than the system }\end{array}$ & Cooperation among clinicians is a priority \\
\hline
\end{tabular}

option for a few, concerns regarding the knowledge base underlying training in family medicine, and uncertainty about the intrinsic value of some of the services provided by family physicians. ${ }^{41}$

Historian Rosemary Stevens argued that 3 things helped explain the situation of family medicine ${ }^{42}$ :

- Family medicine lacked a clearly established role through a formal, nationwide administrative structure for primary care.

- There was insufficient differentiation of family medicine from the rest of medicine while becoming entrenched in the medical establishment as a specialty, but only 1 of several overlapping and competing primary care fields.

- A difficult environment resulted from simultaneously too many and too few changes in the cultural and political scene of the United States to establish family medicine as a foundation of health care as originally envisioned.

Looking inward at the discipline, some suggested that McWhorter's work outside medicine ${ }^{43}$ identified a cultural malady that might also be at work among family physicians and could partially explain what some have viewed as a failure of family medicine to achieve its full potential. To some extent, family physicians could be characterized as preferring to be separate, anti-intellectual, and victimized. Many recognized that a time had arrived when family physicians needed and were needed to connect, integrate, discover, and lead toward a high-performance health care system.

\section{RESEARCH}

In this context, the leaders of 7 national family medicine organizations agreed it was essential that family medicine be responsive to the needs and demands of the public and agreed to take the lead toward constructive change based on quantitative and qualitative research. As a key preparatory step to the development of this report, the organizations chartered a national study conducted by independent contractors (Greenfield Consulting Group and Roper ASW) to develop an objective, unbiased understanding of the contemporary situation of family medicine in the United States. This research was guided by the following questions:

- What are people's perceived health care needs and what are their perceptions about how family physicians can meet those needs?

- What are the challenges family medicine must overcome to meet contemporary expectations of people?

- Why, if at all, would people select and prefer family physicians as their primary physicians?

- What, if anything, is distinct about family physicians?

- Is there a group for which family medicine is irrelevant or makes no sense? If so, who?

- What are family medicine's most promising, but unrealized opportunities?

- Do people desire the core attributes of family practice (eg, first contact, continuity, community basis and context, comprehensiveness)?

In 2002, the study contractors first conducted qualitative research involving 15 interviews with thought leaders in and outside family medicine, 5 focus groups with family physicians; 13 focus groups with patients (2 groups with patients who had a family physician, 4 
groups with patients across the adult age ranges who did not have family physicians, 2 rural groups, 1 chronically ill group, 1 Hispanic group, 1 Asian group, 1 AfricanAmerican group, and 1 inner-city group), 3 focus groups with medical subspecialists; 3 with managed care/payers; 2 with medical students; 2 with resident physicians; and 1 with nurse practitioners. A national probability sample of the public was then queried using standard methods, sampling 1,031 patients, 125 additional parents of children, 300 family physicians, 75 academic family physicians, 75 non-primary-care medical specialists, 100 medical students, and 150 residents in medical training. Further one-on-one interviews were conducted with family physicians, payers, advocacy groups, benefits managers, Medicare and Medicaid administrators, nurse practitioners, and patients.

The qualitative and quantitative research produced a wealth of findings, ${ }^{44}$ including the following:

- Family physicians are not recognized by the public for what they are and what they do. Nor are family physicians distinguished by the public from a host of other health care providers, many of whom are not medically trained. Indeed, the words "family" and "practitioner" were often found to confuse people and suggest that family physicians lack scientific background and competence. A host of terms (PCP, primary care provider, gatekeeper, family practitioner, family practice doctor, generalist, general practitioner, general physician) confuse people.

- General internists also lack recognition among the public. The services they provide and the roles they play are more similar to than different from family physicians. General pediatricians are well recognized as baby doctors, especially for preschool children.

- Patients want their primary care physician to meet the following 5 basic criteria: to be in their insurance plan, to be in a location that is convenient, to be able to schedule an appointment within a reasonable period of time, to have good communication skills, and to have a reasonable amount of experience in practice.

- Beyond the basic criteria, patients value the relationship with their physician above all else, including service. Patients value a physician who listens to them, who takes time to explain things to them, and who is able to coordinate effectively their overall care.

- There is some skepticism regarding the concept of a comprehensive care provider who treats a broad range of health care problems. At least in part, this reaction is based on the belief that it is unrealistic to expect any one physician to be able to keep up with all of the advances in medicine.

- Family physicians were rated as "excellent" or "very good" by a clear majority of survey respondents on the top 5 relationship-related attributes identified by patients: nonjudgmental, understanding, and supportive $_{i}$ honest and direct; acts as partner in maintaining health; listens effectively; and attends to patients' emotional and physical health.

- While patients rank relationship-based attributes most highly, there is a tension between the desire to have a primary physician who is able to treat many illnesses and who treats the patient as a whole person and the perception that it is not possible for any one physician to be knowledgeable and skilled in all areas of medicine.

- The US population is enamored with science and technology and they want their physicians to be technologically savvy. By and large, however, the public does not associate family physicians with science and technology.

- Patients have a hard time differentiating family medicine from other primary care specialties, notably not distinguishing clearly between family medicine and general internal medicine.

- Only about 1 in 10 Americans spontaneously named family physicians as primary care specialists.

- Of those who have a family physician as a primary care physician, $38 \%$ were not aware that their physician was a family physician.

- Of those who believed that their primary care physician was a family physician, in $33 \%$ of the cases that perception was incorrect.

- Patients expect high-quality health care, but instead of using quality as a selection criteria for physicians, they often assume that it exists. Patients tend to judge health care on relationships and rate family physicians highly in this regard. Because patients value relationship so highly and assume the quality of their care is high, they may forgive many of the inadequate service aspects of their care.

It is critical to understand evolving patient expectations. In addition to influencing the future shape and direction of health care in the United States, they present opportunities and challenges for the redesign of the work and workplace of family physicians. As a result, one key challenge to family medicine as it goes about reinventing itself is not only to heed current knowledge on patient expectations, but to predict accurately emerging desires and expectations; in a sense, to help shape the expectations of their patients.

\section{CHALLENGES AND OPPORTUNITIES FOR THE FUTURE}

Based on an analysis of the findings on patient perceptions and expectations, along with research on the attitudes and perceptions of family physicians, medical students, subspecialists, family medicine residents, and 


\section{Table 3. Major Challenges Facing Family Medicine}

\section{Generating an understanding of family practice.}

Despite its 30-year history, neither the general public nor health care professionals understand all that family practice represents

Organizing individuality.

There is significant variance in practice scope from one family physician to the next. As a specialty, family medicine has deliberately resisted specific definition from the beginning

Winning respect in academic circles.

Family medicine suffers as a result of not having gained the respect and resultant endorsement of key academic institutions. Some medical schools feel that family medicine will bring neither money nor recognition to the school; as a result, they neither support the specialty nor encourage students to pursue it

Making family medicine an attractive career option.

Issues requiring attention include: inadequate remuneration, little recognition in the medical field, managed care challenges, quality of care yielding to pressures to increase the quantity of visits, and specialists thinking general internists are better diagnosticians than family physicians

Addressing the obsession with science and technology in the United States.

Family medicine is associated with neither; some people think family physicians are old-fashioned and cannot handle more critical health issues. There is a conspicuous absence of family medicine breakthrough research

residents in other specialties, 5 major challenges were identified that will influence the future viability of family medicine (Table 3 ).

These challenges were centered around developing a broader, more accurate understanding of the specialty; addressing the wide scope and variance in practice types within the family medicine umbrella; winning respect for the specialty in academic circles; making family medicine a more attractive career option; and dealing with the perception that family medicine is not solidly grounded in science and technology.

After reviewing the research findings and considering the implications of these 5 challenges, the task force concluded that unless there are changes in the broader health care system and within the specialty, the position of family medicine in the United States will be untenable in 10- to 20-years.

The summative finding of the specialty being in an untenable position unless changes are made was startling and conflicted with evidence about the contemporary importance of family physicians. For example, there are more family physicians than any other single category of primary care physician (Table 4), and unlike when the specialty was formed, there is now a substantial clinical workforce committed to primary care and a growing number of family physicians.

Furthermore, as shown in Figure 3, many counties would become shortage areas without their family physicians.

Figure 4 shows that physicians' offices, particularly primary care physicians' offices, are the location where more people receive formal health care than any other;
Table 4. Estimated Number of Professionals in the United States in 2000

\begin{tabular}{lc}
\hline Category & Number \\
\hline Family physicians/general practitioners & 86,321 \\
& $(71,106 \mathrm{FP}+15,215 \mathrm{GP})$ \\
General internists & 70,362 \\
General pediatricians & 39,176 \\
Osteopathic family physicians/general & 28,407 \\
practitioners & 102,829 \\
Nurse practitioners & 45,311 \\
Physician assistants & \\
\hline Source: The Robert Graham Center, Washington, DC. \\
\hline
\end{tabular}

indeed, 14 times as many people receive care in a primary care physician's office in an average month as receive care in a hospital.

Furthermore, people beset with the nation's priority health problems rely on family physicians and general internists as their usual source of care (Table 5).

Indeed, the latest nationally representative data available (2000 National Ambulatory Medical Care Survey) confirmed that family physicians continued to be the medical specialty providing more office-based visits (199 million) than any other specialty, ${ }^{45}$ while independent practice by nurses, as proposed by some, ${ }^{46}$ was virtually undetectable in national data sets.

Disturbing trends were confirmed, however, using additional data from sources other than the FFM research project. For example, the proportion of visits to family physicians for acute, chronic and preventive care was found overall to be in decline (Table 6).

A steady and progressing decline in the percentage of US physicians who were family physicians from 1980 through 1999 was confirmed, accompanied by a persistent pattern of high productivity by family physicians in terms of numbers of visits. The combined trends of family physicians comprising a decreasing proportion of the physician population and conducting a smaller proportion of the visits people made to physicians were not the situation for other primary care physicians and other specialists (Figure 5).

The task force reviewed and debated the FFM research findings and reached a consensus that the findings should generally be accepted. The task force also concluded, however, that the problems afflicting family physicians did not include irrelevance or obsolescence. They recognized that family medicine is being affected by a combination of factors that are at once problems and opportunities: fundamental inadequacies in the US health care system that include inappropriate and inadequate financing arrangements, unprecedented knowledge and technological advances, and mismatches between what is needed and wanted by people and 
Figure 3. Simulation of whole county primary care health professions shortage areas (PCHPSAs) without family physicians (FPs) in 1999.

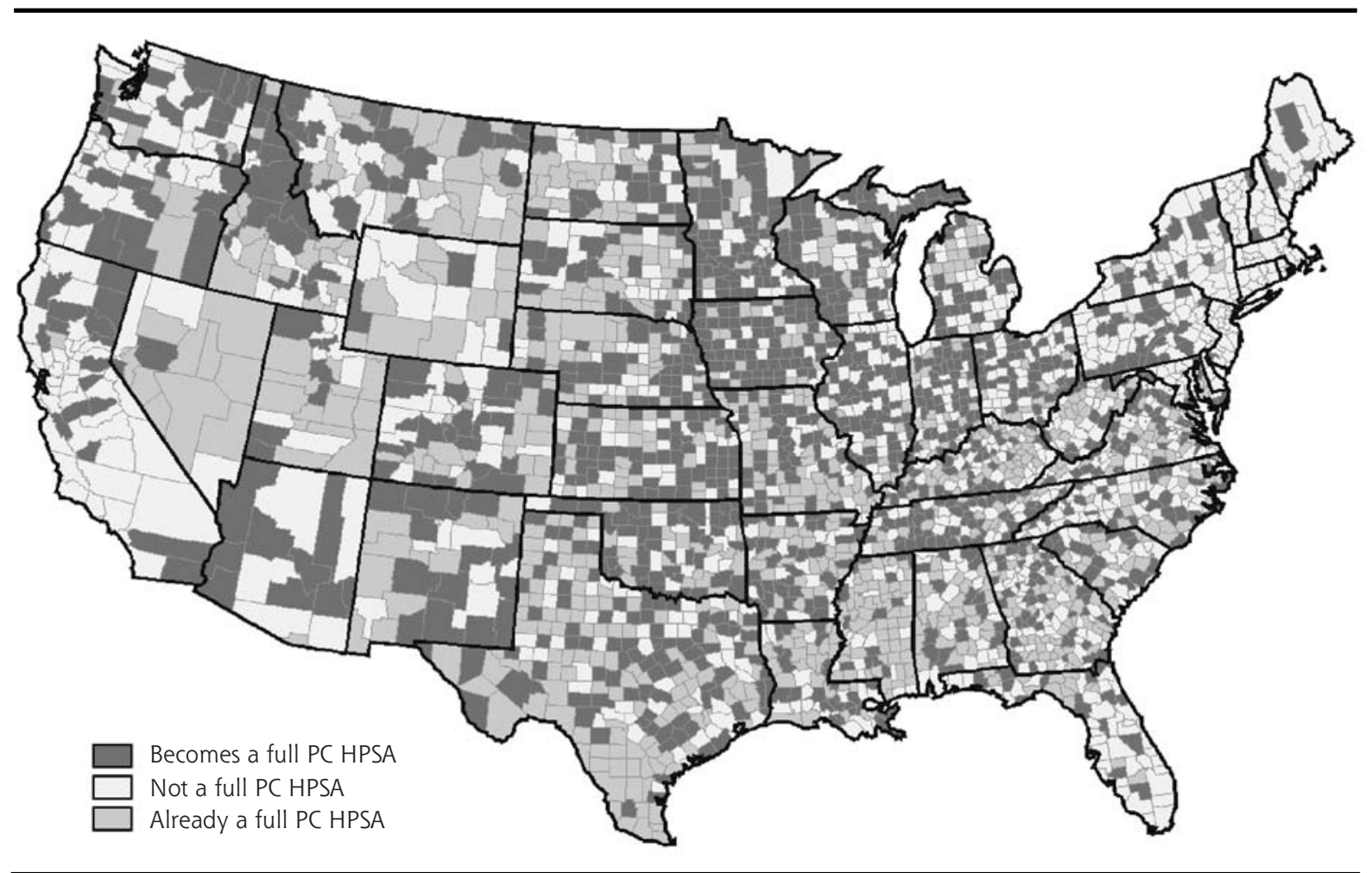

$\mathrm{PC}=$ primary care; $\mathrm{FP}=$ family physicians; HPSA = health professional shortage area.

Source: The Robert Gaham Center: Policy Studies in Family Practice and Primary Care.

Figure 4. The ecology of medical care revisited.

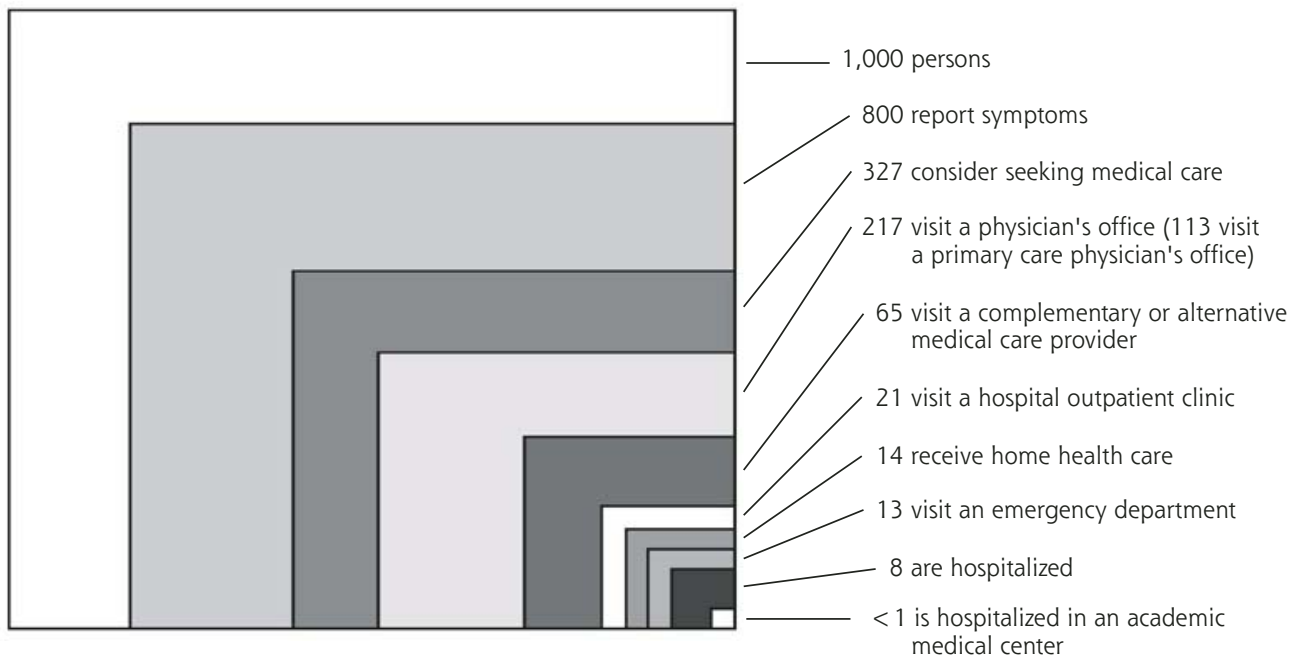

Note: All numbers refer to discrete individual persons and whether or not they received care in each setting in a typical month.

From: Green LA, Fryer GE Jr, Yawn BP, Lanier D, Dovey SM. The ecology of medical care revisited. N Engl J Med. 2001;344:2021-2025. Reprinted with permission from the Massachusetts Medical Society. 


\begin{tabular}{|c|c|c|c|c|}
\hline Condition & $\begin{array}{l}\text { Family Medicine } \\
\%\end{array}$ & $\begin{array}{c}\text { General Internal } \\
\text { Medicine } \\
\%\end{array}$ & $\begin{array}{c}\text { General } \\
\text { Pediatrics } \\
\%\end{array}$ & $\begin{array}{c}\text { All Others } \\
\%\end{array}$ \\
\hline $\begin{array}{l}\text { Arteriosclerotic } \\
\text { cardiovascular disease }\end{array}$ & 56 & 31 & 0.0 & 14 \\
\hline Stroke & 56 & 34 & 0.9 & 9 \\
\hline Hypertension & 63 & 28 & 0.2 & 8 \\
\hline Diabetes & 67 & 23 & 0.6 & 10 \\
\hline Cancer & 60 & 26 & 2.3 & 11 \\
\hline $\begin{array}{l}\text { Chronic obstructive } \\
\text { pulmonary disease }\end{array}$ & 62 & 22 & 5.4 & 11 \\
\hline Asthma & 58 & 15 & 20.8 & 6 \\
\hline Anxiety, depression & 62 & 20 & 7.0 & 11 \\
\hline
\end{tabular}

what family physicians are positioned currently to provide. Previous approaches to primary care and models of family practice are inadequate. Critical contributions of primary care and family medicine that are essential to high-performance health care are struggling to survive, much less excel, in a chaotic, almost malevolent health care system gone awry. The next time for change and adaptation has arrived.

\section{THE WAY FORWARD}

Functioning within a health care system that is broadly viewed as flawed and failing, and where the specialty is both underappreciated and underrecognized, family medicine nevertheless finds many of its core attributes highly sought after by the American public. The results

\begin{tabular}{|lcc|}
\hline \multicolumn{3}{|c|}{ Table 6. Proportion of Visits to Family Physicians } \\
and General Practitioners & for Selected Problems \\
\hline Problem & 1980-1992 & 1993-1999 \\
\hline General examination & 40 & 37 \\
Pharyngitis & 48 & 41 \\
Otitis Media & 30 & 24 \\
N1 pregnancy & 18 & 10 \\
Contraception & 23 & 21 \\
Menopause & 31 & 16 \\
Asthma & 28 & 26 \\
Diabetes & 41 & 34 \\
Obesity & 62 & 48 \\
High blood pressure & 49 & 41 \\
Migraine & 38 & 34 \\
Benign prostatic hypertrophy & 8 & 15 \\
Depression & 39 & 39 \\
All & 30 & 25 \\
\hline Source: Based on National Ambulatory Medical Care surveys, National Center for \\
Health Statistics, us Public Health Service. & \\
\hline
\end{tabular}

of the extensive FFM survey research make it clear that the future contributions and well-being of the discipline lie, in part, in the ability of family medicine to rearticulate its vision and competencies in a fashion that has greater resonance with the public while substantially revising the organization and processes by which care is delivered. When accomplished, family physicians will achieve more fully the aspirations articulated by the specialty's core values.

Even within the constraints of today's flawed health care system, there are great opportunities for family physicians to redesign their models of practice to realize improved results for patients and economic success. In fact, because major elements of the US health care system are in disarray, an environment exists where the reconfiguration and reengineering of the basic elements of office-based family medicine may meet less resistance-and more outright demand - than would be the case in a system more generally viewed as performing adequately. To realize fully the aspirations of the discipline, however, there must be major changes both in the organization and financing of health care services in the United States and within the specialty itself.

The undertaking of major change always carries with it equal elements of risk. Certainly risks exist for family medicine as it strives to leave old patterns and practices behind while mapping out a new course that will express adequately its values and reengineer its processes. The alternative of the status quo, on the other hand, carries its own and perhaps greater risk.

The extensive research and analyses conducted as part of this study provide a better understanding of the essential building blocks for a more effective, modern family medicine specialty - a discipline that would be more highly recognized and valued by the public. The challenge now facing family medicine is to take the initiative for change, engage others truly committed to reform, and to see it through-in all its complexities and risks-to a successful conclusion.

In preparing to move the specialty of family medicine forward, it is important first to articulate the core values and competencies, key characteristics, and identity that underlie the specialty and that position it favorably to meet the challenges and opportunities of the future. 
Figure 5. Percentage of physician population compared with percentage of visits seen.

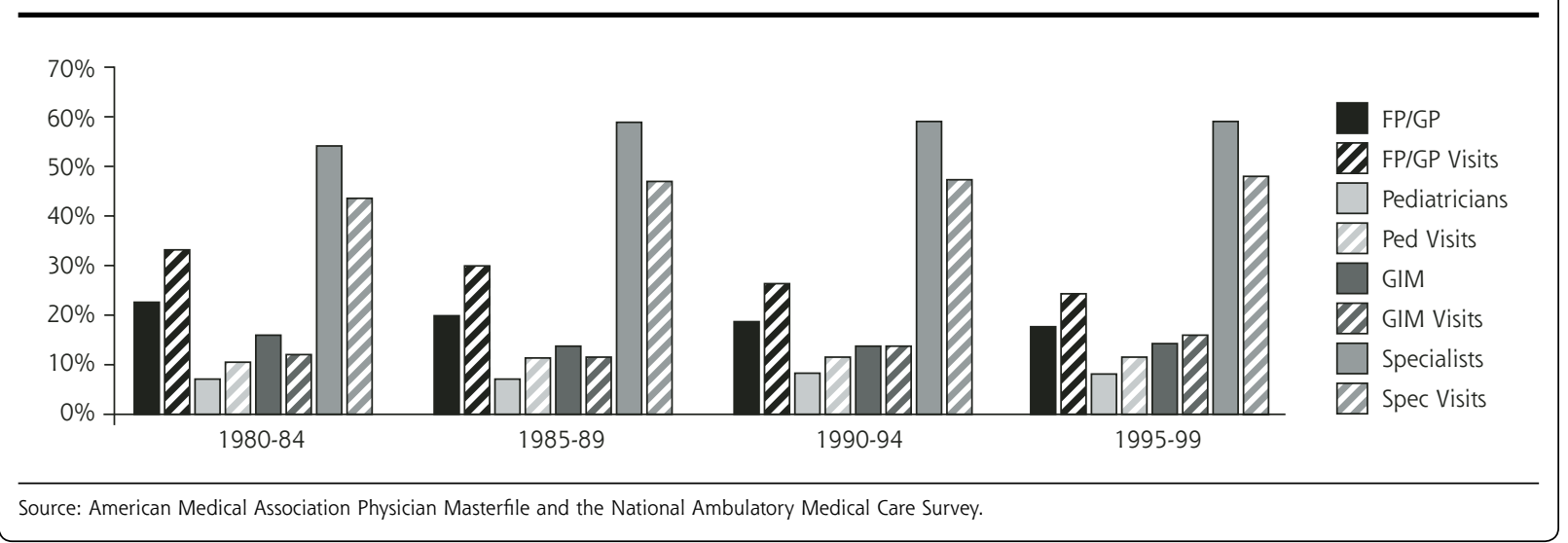

\section{Core Values and Competencies}

A necessary step in defining a new system of practice for family physicians is to affirm the core values of the specialty which are responsible for much that the public currently values and trusts in family physicians. A challenge to family medicine is to articulate these core values in a sufficiently distinctive way so they are recognized by the public as central to what people seek from their personal physician. To date, family medicine has not succeeded in communicating to the public what family physicians are or what they do.

Family physicians are committed to continuing, comprehensive, compassionate, and personal care for their patients. They are concerned with the whole person, and understand that health and disease involve the mind, body, and spirit and depend in part on the context of patients' lives as members of their family and community. ${ }^{37,38,47}$

Continuing care means providing care that fosters trustful relationships between patients and physicians over time. Comprehensive care provides access to what is needed for people of any and all backgrounds and life circumstances; in addition, it ensures the family physician is knowledgeable and willing to accept any type of problem and take responsibility either to provide the care or assure that care is provided by an appropriate source. Compassion involves actually caring, not just giving care. ${ }^{48,49}$ Compassion often enables long-term relationships with patients and families that can deepen with time and allows family physicians to share with their patients the feelings of joy of health, the pain of ill-health, and the grief associated with the loss of health and life itself. Personal care is just that-personal, individualized to each patient's needs, values, and culture.

\section{Personal Characteristics and Competencies of Family Physicians}

The personal and professional attributes expected of family physicians have evolved from the long history of relationships between patients and their personal physicians and are embraced in ideas of professionalism relevant to all physicians. ${ }^{50,51}$ The nature of the work and role of family physicians requires other characteristics and competencies that suit some individuals better than others. . $^{52,53}$

Family physicians must be comfortable dealing with people of all ages and both sexes in situations that vary in their complexity, certainty, and acuity. They must be broadly trained with sufficient depth of knowledge to be competent and confident in treating common ills, some important uncommon problems, and problems that may be specific to their patient population..$^{54}$ The ability to deal with the inherent breadth, unpredictability, and complexities of everyday practice while providing science-based, effective, and compassionate care is a central attribute of family physicians. Family physicians must be adaptable to the wide variety of problems and situations that affect their patients and include evolving diagnoses and changing therapeutic recommendations and interventions necessary to meet the needs of each patient in the context of his or her culture and values. ${ }^{55}$

Cognizant of the community setting in which their patients live and work, family physicians should be able to delineate community health problems as they affect the health of individual patients and develop plans for appropriate intervention. Individuals who respect all persons regardless of their backgrounds, culture, socioeconomic status or life situation and have a deep understanding of human nature excel in this role. The ability to identify with people and connect interpersonally reassures patients and is the beginning of healing relationships that can produce maximum health benefits.

Clear communication with each patient, other involved persons, and the rest of the health care system is necessary to integrate patients' care. ${ }^{56}$ This ability requires simple, honest, open, and caring communication free of jargon or vocabulary that few understand. 
The questions and concerns of all involved need to be considered. Effective communication involves maintaining an open mind to new information and evolving situations. A willingness to obtain additional opinions and information is essential.

Today's ideal family physician is driven by curiosity. What is there about this patient that is contributing to his or her disease? How effectively is the health care system responding to the needs and wishes of this patient? The process of learning and discovery is lifelong, and the opportunities to learn about health and disease as viewed daily by family physicians are abundant. ${ }^{57-59}$

\section{The Necessary Environment for High-Quality Practice}

In the landmark Chasm Report, the IOM defined the framework for the health care system of the $21^{\text {st }}$ century. According to the IOM, a health care system should be safe, effective, patient centered, timely, efficient, and equitable. ${ }^{40}$ Family medicine's core values of continuous, comprehensive, compassionate and personal care are congruent with these rules and probably essential to their realization.

To achieve top performance, family physicians must work in a practice environment that fully promotes these transforming rules. On a daily basis they must practice scientific, evidence-based, patient-centered care, and accept a measure of responsibility for the appropriate and wise use of resources. To assure every person in America a personal physician and to achieve the quality of care that could exist for everyone, family physicians will necessarily work in teams within and beyond their practice setting, focusing on the integration of care for each of their patients over time. To do so requires systems that enhance quality by maintaining access to comprehensive, compassionate, personalized care; reducing unwanted variability in diagnosis and treatment; reducing errors of misuse, overuse, and underuse, and measuring results for individuals and populations under care..$^{40,60}$

\section{Managing Relationships, Information, and Processes}

Looking to the future, family physicians must not only have the requisite skills in diagnosis, treatment, and performance of procedures, they must also demonstrate competencies in managing relationships, information, and processes. ${ }^{61,62}$

\section{Relationship Management}

Because a continuous healing relationship is the essence of care, family physicians must be able to establish and maintain systems and procedures that sustain an ongoing partnership with patients and enable timely access to the services their patients need. Face-to-face contact must be supplemented with telephone, fax, e-mail, and Internet interaction to enhance the flow of information and promote the resolution of problems. The patient should be able to say: "My personal physician gives me exactly the care I need, exactly when I need it."

\section{Information Management}

The complexity of caring for people with acute and chronic problems and managing preventive services for populations of patients requires the involvement of many health professionals working in well-organized systems and supported by information technology. ${ }^{63}$ Family physicians will rely increasingly on information systems and electronic health records to provide assessments, checklists, protocols, and access to patient education and clinical support. Clinical information must be maintained in formats that allow for ready search, retrieval, and transfer of information while protecting patients' privacy and the confidentiality of their medical records. Electronic health records with a relational database design and meeting national technical standards are essential. The paper medical record can no longer provide the needed foundation for the clinical care and research of family physicians.

\section{Process Management}

All physicians work in systems of care. Some family physicians work in small systems; others work in very large systems. Family physicians and their health professional colleagues must assume responsibility for the constant assessment and improvement of their care. Patients, the central focus of the family physician's enterprise, are crucial participants in many of the processes of care and share responsibility for achieving appropriate and successful care. Working together on behalf of patients requires teamwork that occurs in a complex web of relationships and services. It requires skillful management with appropriate authority and collaboration, as well as a mindset of vigilance and continuous process improvement. ${ }^{37}$

\section{Identity and Key Characteristics}

Based on a careful analysis of the research findings, the FFM Project Leadership Committee adopted the following identity statement for family medicine: Family physicians are committed to fostering bealth and integrating bealth care for the whole person by bumanizing medicine and providing science-based, bigh-quality care. This statement is derived from and intertwined with the 5 key characteristics of family physicians, which form the foundation for the specialty's identity (Table 7 ). ${ }^{44}$

These 5 characteristics might be articulated differently and more simply, as follows. 


\begin{tabular}{|c|c|}
\hline Characteristic & Description \\
\hline $\begin{array}{l}\text { A deep understanding of the dynamics } \\
\text { of the whole person }\end{array}$ & $\begin{array}{l}\text { This approach leads family physicians to consider all the influences on a person's health. It helps to inte- } \\
\text { grate rather than fragment care, involving people in the prevention of illness and the care of } \\
\text { their problems, diseases, and injuries }\end{array}$ \\
\hline A generative impact on patients' lives & $\begin{array}{l}\text { This terminology comes from Erik Erikson's work on personality development. Family physicians } \\
\text { participate in the birth, growth, and death of people and want to make a difference in the lives of } \\
\text { their patients. While providing services that prevent or treat disease, family physicians foster personal } \\
\text { growth in individuals and help with behavior change that may lead to better health and a greater } \\
\text { sense of well-being }\end{array}$ \\
\hline $\begin{array}{l}\text { A talent for humanizing the health care } \\
\text { experience }\end{array}$ & $\begin{array}{l}\text { The intimate relationships family physicians develop with many of their patients over time enables } \\
\text { family physicians to connect with people. This ability to connect in a human way with people allows } \\
\text { family physicians to explain complex medical issues in ways that people can understand. Family } \\
\text { physicians take into account the culture and values of their patients, while helping them get the } \\
\text { best care possible }\end{array}$ \\
\hline A natural command of complexity & $\begin{array}{l}\text { Family physicians are comfortable with uncertainty and complexity. They are trained to be inclusive, } \\
\text { to consider all the factors that lead to health and well-being- not just pills and procedures }\end{array}$ \\
\hline $\begin{array}{l}\text { A commitment to multidimensional } \\
\text { accessibility }\end{array}$ & $\begin{array}{l}\text { This means not only to be physically accessible to patients and their families and friends, but to } \\
\text { maintain open, honest, and sharing communications with all involved with the care process }\end{array}$ \\
\hline
\end{tabular}

It is the person that matters most. Family physicians want their patients to have longer and better lives. The patient is not a machine in for a tune-up. Problems are usually multifactorial, and patients do not always choose optimally, but we can continue to do our best with what is available. Sometimes patients just need to unburden themselves with their physician.

Exactly how these characteristics are stated is less important than recognizing their contemporary importance and that they enhance the core values of family physicians the public finds attractive and valuable. The core values of continuing, comprehensive, compassionate, and personal care in the context of family and community have contributed positively to the development of family medicine and its identity as a discipline. They have shaped the identity of individual family physicians and have contributed to establishing a legitimate position for family physicians in academia and in the larger medical community. ${ }^{64,65}$

It is these core values-not a list of particular services-that distinguish family physicians from other health care providers. The public is hungry for these attributes as the current health care system becomes increasingly fragmented and impersonal. ${ }^{44,66-69}$ To realize fully the specialty's potential and meet the needs of patients more completely, however, a new model of practice, along with more global changes in how the US health care system is organized and financed, is required.

\section{A New Model of Practice}

The shortcomings of the current US health care system and dissatisfaction with it provide family physicians with a compelling opportunity to improve the health of the nation and influence their own destinies by redesigning their model of practice. The 6 aims and 10 new rules that were enumerated in the IOM Chasm Report (Tables 1 and 2), along with the key characteristics (Table 7) and identity statement for family medicine developed as part of this study, provide a compelling vision to guide the development of the New Model of family medicine (New Model). This New Model must be traditional enough to reflect and sustain enduring principles and values, familiar enough to be understandable, bold enough to attract interest and capital, and not so idealized as to be impractical in the immediate future.

The critical bridge between the expression of the core values of family medicine as a medical discipline and the New Model of care in which the family physician's patients will be cared for is the relationships between the physician, the practice, and the patient. The identity of family physicians is centered upon the need to make people whole by humanizing medicine and providing science-based health care and medical services. The commitment to make people whole has major implications for the redesign of the specialty of family medicine. People cannot become whole in a system that is fragmented. ${ }^{70}$

The challenge, therefore, is one of configuring family medicine in such a way that people will walk out of their family physician's office not only feeling cared for, but also feeling that they are being guided appropriately through and represented within the larger health care system. This outcome will require a reintegration of the patient, the practice, other providers and organizations, and ultimately the larger health care system. ${ }^{71}$ Only through such a reintegration will safe, effective, patient-centered, timely, efficient, and equitable care be possible.

For family medicine to contribute substantially to the reintegration of medicine, family physicians will need to reconceptualize their role and redesign their practices. 


\begin{tabular}{|c|c|}
\hline Characteristics & Description \\
\hline Patient-centered care & $\begin{array}{l}\text { Patients are active participants in their health and health care. The practice } \\
\text { has a customer service orientation that embraces the importance of } \\
\text { meeting patients' needs, reaffirming that the fundamental basis for } \\
\text { health care is "people taking care of people."72 }\end{array}$ \\
\hline $\begin{array}{l}\text { Whole-person } \\
\text { orientation }\end{array}$ & $\begin{array}{l}\text { A visible commitment to whole-person care through such mechanisms } \\
\text { as developing cooperative alliances with services or organizations } \\
\text { that extend beyond the practice setting, but are essential for meeting } \\
\text { the complete range of needs for a given patient population. }{ }^{37} \text { The } \\
\text { practice has the ability to help guide a patient through the health } \\
\text { care system by integrating their care-not simply coordinating it }\end{array}$ \\
\hline A team approach & $\begin{array}{l}\text { An understanding that health care is not delivered by an individual, } \\
\text { but rather by a system, }{ }^{40} \text { which translates to the development of } \\
\text { a multidisciplinary team approach for delivering and continually } \\
\text { improving care for an identified population. }{ }^{73}\end{array}$ \\
\hline $\begin{array}{l}\text { Elimination of barriers } \\
\text { to access }\end{array}$ & $\begin{array}{l}\text { Elimination, to the extent possible, of barriers to access by patients } \\
\text { through implementation of open scheduling, expanded office hours, } \\
\text { and additional, convenient options for communication between } \\
\text { patients and practice staff }\end{array}$ \\
\hline $\begin{array}{l}\text { Advanced information } \\
\text { systems }\end{array}$ & $\begin{array}{l}\text { The ability to use an information system to deliver and improve care, } \\
\text { to provide effective practice administration, to communicate with } \\
\text { patients, to network with other practices, and to monitor the health of } \\
\text { the community. }{ }^{74,75} \mathrm{~A} \text { standardized electronic health record, adapted } \\
\text { to the specific needs of family physicians, constitutes the central } \\
\text { nervous system of the practice }\end{array}$ \\
\hline $\begin{array}{l}\text { Attractive, convenient, } \\
\text { and functional offices }\end{array}$ & $\begin{array}{l}\text { Office facilities that are attractive, convenient, and functional in order to } \\
\text { meet a variety of patient needs and expectations }\end{array}$ \\
\hline Focus on quality & $\begin{array}{l}\text { Ongoing assessment of performance and outcomes and implementation } \\
\text { of appropriate changes to enhance quality }\end{array}$ \\
\hline $\begin{array}{l}\text { Equitable } \\
\text { reimbursement }\end{array}$ & $\begin{array}{l}\text { Payment mechanisms that provide for equitable reimbursement for } \\
\text { services from public and private payers }\end{array}$ \\
\hline
\end{tabular}

Whole-Person Orientation

The focus of New Model practices will be whole person care designed to meet the complete range of needs of the population they serve. ${ }^{37}$ While patients are ultimately responsible for their health, the family physician in a New Model practice will conceive of himself or herself as the chief consultant and advisor to each patient's health care. The practice will provide or integrate all of their patients' care. Family physicians will consider not only what they can do for their patients, but also what other resources and services are available in the community to meet patient needs. When a family physician cannot provide specific services personally, he or she will refer patients to the appropriate source of care for their particular needs.

The New Model practice will continue to provide care across ages, genders, socioeconomic classes, and settings. Accepting the complexity of health and health care, the New Model practice will provide multiple ways for patients to access care and will be open to the different ways those from varying socioeconomic backgrounds seek and accept medical care. Such a practice will be a system that models the very whole-person orientation that patients can expect in the care that they receive. While the office setting will continue to be an important site for care, it is important to emphasize that to integrate patient care effectively, future family physicians will need to be prepared to deliver their full basket of services wherever they are needed.

\section{Team Approach}

Patient care in the New Model will be provided through a multidisciplinary team approach and will be dependent on a deep understanding of the population served by the practice. In addition to the usual clerical and nursing personnel, staffing will typically include physician assistants and nurse practitioners, as well as nutritionists, health educators, and behavioralists in some cases. Some of these staff might only work in the practice on a part-time basis.

A cooperative effort among all practice providers and staff will be the cultural norm, and it will be understood that the practice is more than the sum of 
its individual parts. Practice staff will share in decision making regarding patient care, with explicit accountability for their work to patients, to each other, and to each patient's personal physician. Systems of care will be honored and supported. New Model practices will develop collaborative relationships with specialists for the purposes of improving and better integrating patient care. Some specialists may see patients on-site at New Model practice facilities.

\section{Elimination of Barriers to Access}

Under the New Model, barriers to patient access will be removed. Practices will use an open scheduling model for scheduling patient visits (ie, the patient usually will be able to make an appointment for the same day, regardless of the type of problem or visit required), while offering flexible and expanded office hours.

The practice will provide a convenient mechanism for telephone communication with a staff person-not an answering machine or voice mail—on a 24-hour-a-day, 7-day-a-week basis. In areas where multiple practices exist, New Model practices will be networked for providing emergency services on site in one practice when other practices are closed, with communication links in place to assure seamless communication to the patient's physician regarding the urgent care provided.

Interactions will not be limited to traditional, individual, face-to-face encounters between the patient and the family physician. Depending on the particular circumstances, patients may or may not receive faceto-face care and may or may not be seen by a physician. For example, they may receive on-site care from another member of the multidisciplinary team or may have their needs met through asynchronous communication with a family physician. New Model practices will develop a Web portal and will utilize secure e-mail to provide additional, convenient options for communication between patients and practice staff. Patients will be able to make appointments online through the practice Web site and will be able to access online patient education materials appropriate to their health status. Implementing creative alternatives to the traditional one-on-one office-based approach to care, combined with successful advocacy for changes in health care payment policies, will be necessary if family physicians are to get off the current treadmill of having to see 30 to 40 patients a day to survive financially.

\section{Information Systems}

- A standardized electronic health record (EHR), adapted to the specific needs of family physicians, will constitute the central nervous system of the New Model practice. Such an EHR will have the following characteristics and capabilities:
- Embedded evidence-based clinical practice guidelines for enhancing the management of patients with the most common conditions encountered in family medicine practices

- Order entry and referral tracking system

- Managed care organization-specific pharmacy formulary

- Web-enabled access to data repositories, with appropriate levels of security

- Capability of generating chronic disease registries, which will ensure that patients can be recalled for care at appropriate time intervals

- Capability of tracking health maintenance interventions and generating physician and patient reminders for personalized preventive services

- Capability of being integrated with common practice management and billing systems

- Some availability to patients by means of Web interface, for entry of self-care data, patient history data, health-related quality of life measures, mental health screening questionnaires, and other applications

- Capability to support practice-based clinical research using electronic audits concerning the costs, processes, and outcomes of care (including the Health Plan Employer Data and Information Set or similar measures)

In addition to the EHR, the New Model practice will have computerized decision support systems-ideally Web-based - to help patients make better, more informed health care decisions and to facilitate the process through which the family physician explains patient options. In addition, just-in-time information systems for physicians will allow rapid retrieval of best, up-to-date evidence at the point of care.

\section{Convenient, Attractive, and Functional Offices}

New Model practice facilities will be convenient, attractive, and functional to meet a variety of patient needs and expectations. The facilities will be designed to accommodate staffing patterns that differ from the current model, including most notably a broader array of health professionals working together as part of a multidisciplinary team. Family medicine offices will be designed purposefully to meet the needs of the population, with special attention to the patient market segments the practice wishes to attract. The practice facility will have space available to accommodate group visits for patients with certain chronic diseases. The group meeting space will be private, comfortable, and able to accommodate 10 or more patients at a time. The traditional waiting room will be replaced by a patient resource center with a small patient library and computer work stations offering ready access to online health education materials. Practices will be equipped with sufficient technology, staff, and supplies to be able to pro- 
vide onsite a comprehensive set of diagnostic services, assessment and testing for important genetic predispositions, and common therapeutic procedures. Most New Model practices typically will be physician owned and configured as group family practices of a workable size. For purposes of capitalization, marketing, economies of scale, and bargaining power, it may be advantageous to form linkages with a larger, umbrella organization.

\section{Focus on Quality}

The New Model practice will seek to improve continuously the quality of patient care. Practices will document quality and safety through ongoing analyses of practice patient care data. Patient feedback will be solicited to ensure that the practice is meeting patients' expectations, satisfying their needs for access to the practice, and responding to the needs of increasingly diverse populations.

Each practice will develop and use a structured, recurring administrative mechanism to examine the measurements of the practice and the patients under care to reflect, adapt and improve; update quality improvement efforts; reduce errors and enhance patient safety; and advance current research projects of the practice. Practice staff, along with representative patients, will be included in these quality improvement processes. New Model practices will place a high priority on taking steps to ensure patients' safety within the practice. Electronic data and decision support systems will play an important role in assuring safe care.

\section{Enhanced Practice Finance}

The dictum "no margin, no mission" will be taken seriously. Improved operating efficiencies will decrease practice expenses and contribute to improved practice margins. Practices will compete for gaining a portion of patients' discretionary spending on health care. New Model practices will be organized to accommodate all payment options while advocating for coverage of all Americans under health insurance plans. New Model practices must be paid equitably to enjoy improved financial margins. Within the constraints of current payment systems, practices will search for ways to bill for appropriate services that are not currently in the allowable charge base. The New Model requires a payment system that blends capitation, fee-for-service, and premium or incentive payments based on measurable processes and outcomes of care.

\section{Core Services in the New Model}

Core clinical services in the New Model will include the management and prevention of acute injuries, illnesses, and chronic diseases; health promotion; and rehabilitation and supportive care, across health care

\section{Table 9. Core Services in the New Model}

Integration of personal care

Health assessment (evaluation of health and risk status)

Disease prevention (early detection of asymptomatic disease)

Health promotion (primary prevention and health behavior/lifestyle modification)

Patient education and support for self-care

Diagnosis and management of acute injuries and illnesses, with referral as appropriate

Diagnosis and management of chronic diseases

Coordination and provision of rehabilitative services

Supportive care, including end-of-life care

Women's health care

Primary mental health care

Advocacy for the patient within the health care system

settings, with a focus on the outpatient setting, where most people are most of the time (Table 9).

The care provided in the New Model will be of the highest quality; it will be evidence based and up to date. Care will be technologically sufficient (sophisticated) and facilitated (enabled), but not technologically excessive or harmful. Physicians practicing within the New Model practice will be very well trained and highly competent. The New Model will require and will attract medical students of the highest caliber into family medicine residency training programs.

State-of-the-art chronic disease management will be an important part of the services provided by New Model practices. The care of patients with chronic diseases will utilize a population-based approach, including the use of disease registries. The practice will adhere to up-to-date, evidence-based clinical practice guidelines, which will be embedded into the EHR. The practice will participate in continuous quality improvement in an ongoing fashion. The management of patients with chronic diseases will involve the multidisciplinary team and will include some care of patients in their homes. The use of new technologies, such as telemedicine, will be explored as ways of enhancing the management of these patients.

Excellent preventive care across the individual life cycle and age spectrum will be another key component of New Model practices. Preventive interventions will be implemented based on the quality of supportive evidence. Standard health-risk assessments will be used for risk factor identification. The EHR will play a key role in tracking adherence to prevention guidelines and in continuously improving the quality of the preventive care provided by the practice. Health behavior and lifestyle modification skills will be essential to the multidisciplinary team providing preventive care in the practice.

Family physicians will participate in the care of their hospitalized patients but will not necessarily 


\begin{tabular}{|c|c|}
\hline Traditional Model of Practice & New Model of Practice \\
\hline $\begin{array}{l}\text { Care is provided to both genders and all ages; } \\
\text { includes all stages of the individual and family } \\
\text { life cycles in continuous, healing relationships }\end{array}$ & $\begin{array}{l}\text { Care is provided to both genders and all ages; } \\
\text { includes all stages of the individual and family } \\
\text { life cycles in continuous, healing relationships }\end{array}$ \\
\hline The doctor is center stage & The patient is center stage \\
\hline Unnecessary barriers to access by patients & Open access by patients \\
\hline Care is mostly reactive & Care is reactive and prospective \\
\hline Care is often fragmented & Care is integrated \\
\hline Paper medical record & Electronic health record \\
\hline An unpredictable package of services is offered & A defined package of services is offered reliably \\
\hline Individual patient oriented & Individual and population oriented \\
\hline $\begin{array}{l}\text { Communication with practice is synchronous } \\
\text { (in person or by telephone) }\end{array}$ & $\begin{array}{l}\text { Communication with the practice is both } \\
\text { synchronous and asynchronous (e-mail, } \\
\text { Web portal, voice mail) }\end{array}$ \\
\hline Quality of care is assumed & $\begin{array}{l}\text { Quality of care is continuously measured and } \\
\text { improved }\end{array}$ \\
\hline The physician is the main source of care & A multidisciplinary team is the source of care \\
\hline Individual physician-patient visits & $\begin{array}{l}\text { Individual and group visits involving several } \\
\text { patients and members of the health care team }\end{array}$ \\
\hline Consumes knowledge & Consumes and produces knowledge \\
\hline Safety is assumed & Systems to insure safety are built in \\
\hline Experience based & Evidence based \\
\hline Haphazard chronic disease management & $\begin{array}{l}\text { Purposeful, organized chronic disease } \\
\text { management }\end{array}$ \\
\hline Struggles financially, undercapitalized & Positive financial margin, adequately capitalized \\
\hline
\end{tabular}

in the financing of health care in the United States, to business security and margin survival for the practice. With appropriate dissemination strategies ${ }^{77} \mathrm{New}$ Model practices should become the premier source of acute care, chronic care, and preventive care within the US health care system.

The New Model is an ambitious, robust model. It expresses important values and continues important traditions of medicine. ${ }^{78}$ With the assets of the United States and a relentless commitment by family physicians to stay the course and work with others, it can be achieved.

\section{RECOMMENDATIONS}

Recommendation 1.1. The professional organizations of family medicine should undertake wholeheartedly a period of active assume full or primary responsibility for patient care in the inpatient setting. The approach taken to hospital care must support the maintenance of continuing, healing relationships with patients, and there should be seamless transitions between different settings of care.

The flexibility and adaptability of the New Model will accommodate, indeed encourage, variation from practice to practice depending on physician interests and training, geographic location, the unique needs of the population being served, and availability of staff. As a result, some practices will provide care beyond the core services or will place greater emphasis on certain core services. Practices will vary in the range of diagnostic and therapeutic procedures performed, the amount and intensity of hospital care provided, the provision of intrapartum maternity care, and the range of extended hours provided by the practice. One size fits all has never been a feature of family medicine, and it will not be characteristic of the specialty under the New Model. Table 10 displays a simple comparison between the traditional model of practice and the New Model.

\section{ANTICIPATED RESULTS AND CONCLUSION}

The New Model should improve the care of patients and their health, the lives of their family physicians and their colleagues, and the performance of an ailing health care system. The New Model should lead to practice advancements, and with appropriate changes experimentation and innovation in the delivery of clinical services and the education of clinicians to ensure the provision of quality health care.

Recommendation 1.2. Family medicine should redesign the work and workplaces of family physicians to create a model of care that supports scientifically valid and evidence-based acute, chronic, and preventive medical care of the highest quality for people of all ages, cultures, and socioeconomic status, delivered in a humane, service-oriented fashion that provides great satisfaction to those who become family physicians and the patients of family physicians.

Recommendation 1.3 . Family medicine should develop and adapt into practice electronic health records and other technologies and systems of care that standardize and enhance (1) communication, (2) diagnosis and treatment, (3) measurement of processes and results, and (4) on-going relationships between family physicians and their patients to make family practices sufficiently robust to provide definitive care for a large portion of the problems that people bring to their family physician.

Recommendation 1.4. To support steps toward making operational recommendations 1.1, 1.2, and 1.3, the Future of Family Medicine Working Party should charge an appropriate group to develop a range of business plans, reflecting differing patterns of revenues and expenses, which could make reengineered family practices economically viable and result in attractive alternatives to current business models. 
Recommendation 1.5. As a companion effort to recommendation 1.4, the Future of Family Medicine Working Party should charge an appropriate group with the responsibility for developing a model and implementation plan for a national resource that would be financially self-sustaining and provide individual practices with ongoing support for reengineered new models of family medicine.

Recommendation 1.6. Throughout the period of experimentation and innovation, family physicians and their organizations should seek out and welcome likeminded groups, who share values and commitment to similar purpose.

To read or post commentaries in response to this article, see it online at http://www.annfammed.org/cgi/content/full/2/suppl_1/S33.

Key words: Physician practice patterns; practice management; workplace; reimbursement mechanisms; patient-centered care; information management; quality assurance; health care; professional practice; social identification; delivery of health care

Funding Support: The Future of Family Medicine Project is supported by the following family medicine organizations: American Academy of Family Physicians (AAFP), American Academy of Family Physicians Foundation (AAFPF), American Board of Family Practice (ABFP), Association of Departments of Family Medicine (ADFM), Association of Family Practice Residency Directors (AFPRD), North American Primary Care Research Group (NAPCRG), and Society of Teachers of Family Medicine (STFM). Major support has been contributed by Eli Lilly Foundation; Pharmacia, Pharmacia Foundation; Pfizer, Pfizer Foundation; and the Robert Wood Johnson Foundation. In addition, generous support has been obtained from the Health Resources and Services Administration, Schering-Plough Corporation, and Wyeth Pharmaceuticals.

Members of Task Force 1: Larry A. Green, MD, Chair, Denver, Colo, and Washington, DC; Stephen P. Bogdewic, PhD, Indianapolis, Ind; Bruce Bagley, MD, Latham, NY; Stephen C. Crane, PhD, MPH, Alexandria, Va; William Jackson Epperson, MD, MBA, Murrells Inlet, SC; Julia Garner, MD, Hardy, Ark; Robert Graham, MD, Bethesda, Md; Cal Gutkin, MD, Mississauga, Ontario, Canada; William Kane, MD, Chapel Hill, NC; Charles M. Kilo, MD, MPH, Portland, Ore; Jeannette South-Paul, MD, Pittsburgh, Pa; Stephen J. Spann, MD, Houston, Tex; John Swanson, MPH, Leawood, Kan; David Kibbe, MD, Leawood, Kan.

Acknowledgments: The task force benefited greatly from the input of many people, including all the members of the Future of Family Medicine Project Leadership Committee, the Family Medicine Working Party, FFM project and task force staff, members of the other FFM task forces, and particularly the group of external reviewers listed below.

Project Leadership Committee: James C. Martin, MD, Project Leadership Committee Chair; Robert F. Avant, MD; Marjorie A. Bowman, MD, MPA; John R. Bucholtz, DO; John C. Dickinson, MD; Kenneth L. Evans, MD; Larry A. Green, MD; Douglas E. Henley, MD; Warren A. Jones, MD; Samuel C. Matheny, MD, MPH; Janice E. Nevin, MD, MPH; Sandra L. Panther, CFRE; James C. Puffer, MD; Richard G. Roberts, MD, JD; Denise V. Rodgers, MD; Roger A. Sherwood, CAE; Kurt C. Stange, MD, PhD; Cynthia W. Weber, MA.

Future of Family Medicine Research Advisory Committee: John R. Bucholtz, DO; John C. Dickinson, MD; Larry A. Green, MD; Warren A. Jones, MD; James C. Martin, MD; Richard G. Roberts, MD, JD; Kurt C. Stange, MD, PhD.
Future of Family Medicine Project Staff: Norman B. Kahn, Jr, MD, FFM Staff Executive; Sarah Thomas, Assistant Staff Executive; Marilyn A. McMillen, MBA, Project Manager; Dorothy Young, FFM Administrative Assistant; Nina Carnoali, FFM Staff Assistant; Ruth Coram, FFM Staff Assistant.

Reactor Panel: Kara Cadwallader, MD; Douglas Campos-Outcalt, MD, MPA; Don Cauthen, MD; Jennifer DeVoe, MD, DPhil; Mark Ebell, MD, MS; Kevin Grumbach, MD; Steven Lawenda, MD; Paul Nutting, MD, MSPH; Frank Reed, MD; Lee Sacks, MD; Bertha Safford, MD; Terrence Steyer, MD; Michael Temporal, MD; George H. White, MD.

\section{References}

1. Millis JS. The Graduate Education of Physicians: The Report of the Citizens Commission on Graduate Medical Education. Chicago, Ill: American Medical Association; 1966.

2. Willard WR. Meeting the Challenge of Family Practice: The Report of the Ad Hoc Committee on Education for Family Practice of the Council on Medical Education. Chicago, III: American Medical Association; 1966.

3. Graham R, Roberts RG, Ostergaard DJ, Kahn NB, Pugno PA, Green LA. Family practice in the United States. A status report. JAMA. 2002;288:1097-1101.

4. Goldsmith J. The road to meaningful reform: a conversation with Oregon's John Kitzhaber. Health Aff (Millwood). 2003;22:114-124.

5. Wilensky GR. Thinking outside the box? A conversation with John Breaux. Health Aff (Millwood). 2003;22:15. Available at: http: //www.healthaffairs.org/WebExclusives/Breaux_Web_Excl_030503.

6. David AK. Necessary change in family medicine: entering adulthood. Fam Med. 2003;35:217-219.

7. Geyman JP. Family practice in a failing health care system: new opportunities to advocate for system reform. J Am Board Fam Pract. 2002;15:407-415.

8. Sox HC. The future of primary care. Ann Int Med. 2003;230-231.

9. Berwick DM. Public performance reports and the will for change. JAMA. 2002;288:1523-1524.

10. Avant RR. Family practice: exclusive, inclusive, or-heaven forbidboth? J Am Board Fam Pract. 2002;15:506-508.

11. Edsall RL. Recreating family practice. Fam Pract Manage. 2002;9:10.

12. Holahan J, Pohl MB. Changes in insurance coverage: 1994-2000. Health Aff (Millwood) Web Exclusive. 2002:w162-w171.

13. Zuvekas SH, Taliaferro GS. Pathways to access: health insurance, the health care delivery system, and racial/ethnic disparities, 1996-1999. Health Aff (Millwood). 2003;22:139-153.

14. Institute of Medicine. Committee on Consequences of Uninsurance. Care Without Coverage: Too Little, Too Late. Institute of Medicine. Washington, DC: National Academy Press; 2002.

15. Fee $E$, Brown TM. The unfulfilled promise of public health: déjà vu all over again. Health Aff (Millwood). 2002;21:31-43.

16. Institute of Medicine. Committee on Assuring the Health of the Public in the 21st Century. The Future of the Public's Health in the 21st Century. Institute of Medicine. Washington, DC: National Academy Press; 2002.

17. Mechanic D, McAlpine DD. Mission unfulfilled: potholes on the road to mental health parity. Health Aff (Millwood). 1999;18:7-21.

18. Iglehart J. The woeful neglect of health care workforce issues. Health Aff (Millwood). 2002;21:7-8.

19. Grumbach K. Fighting hand to hand over physician workforce policy. Health Aff (Millwood). 2002;21:11-27.

20. Reinhardt UE. Dreaming the American dream: once more around on physician workforce policy. Health Aff (Millwood). 2002;21:28-32.

21. Masys DR. Effects of current and future information technologies on the health care workforce. Health Aff (Millwood). 2002;21:33-41. 
22. Ward D, Berkowitz B. Arching the flood: how to bridge the gap between nursing schools and hospitals. Health Aff (Millwood). 2002;21:42-52.

23. Mertz E, O'Neil E. The growing challenge of providing oral health care services to all Americans. Health Aff (Millwood). 2002;21:65-77.

24. Kovner CT, Mezey M, Harrington C. Who cares for older adults? Workforce implications of an aging society. Health Aff (Millwood). 2002;21:78-89.

25. Cohen JJ, Gabriel BA, Terrell C. The case for diversity in the health care workforce. Health Aff (Millwood). 2002;21:90-102.

26. Phillips RL, Harper DC, Wakefield M, Green LA, Fryer GE. Can nurse practitioners and physicians beat parochialism into plowshares? Health Aff (Millwood). 2002;21:133-142.

27. Institute of Medicine. Committee on Understanding and Eliminating Racial and Ethnic Disparities in Health Care. Unequal Treatment: What Health Care Providers Need to Know About Racial and Ethnic Disparities in Health Care. Washington, DC: National Academy Press; 2002.

28. Institute of Medicine. Committee on Quality of Health Care in America. To Err Is Human. Building a Safer Health System. Washington, DC: National Academy Press; 2000.

29. Robert Graham Center. Toxic cascades: a comprehensive way to think about medical errors. Am Fam Physician. 2001;63:847.

30. Levit K, Smith C, Cowan C, Lazenby H, Sensenig A, Catlin A. Trends in US health care spending, 2001. Health Aff (Millwood). 2003;22: 154-164.

31. Watts C, Christianson JB, Heineccius L, Trude S. The role of public employers in a changing health care market. Health Aff (Millwood). 2003; 22:173-180.

32. Ramminger S. Care last. My son is a pawn in the battle between hospital and health insurer. Washington Post Outlook. January 5, 2003:B8.

33. Lieberman T. Bruised and broken: United States health system. AARP Bulletin: Collapse of Our Health Care System. March 2003;44:1-5.

34. Broder DS. Health care hopes. Washington Post Outlook. March 16, 2003:B7.

35. Geyman JP. Health Care in America. Can Our Ailing System Be Healed? Boston, Mass: Butterworth Heinemann; 2002.

36. Reed M, Ginsburg PB, for the Center for Studying Health System Change. Behind the times: physician income, 1995-1999. Data Bulletin. Results from HSC Research Number 24, March 2003. Available at: http://www.hschange.org.

37. Donaldson MS, Yordy KD, Lohr KN, Vanselow NA, eds. Committee on the Future of Primary Care. Institute of Medicine. Primary Care. America's Health in a New Era. Washington, DC: National Academy Press; 1996.

38. Starfield B. Primary Care: Concept, Evaluation, and Policy. New York, NY: Oxford University Press; 1992.

39. Pugno PA, McPherson DS, Schmittling GT, Kahn NB. Results of the 2002 national resident matching program: family practice. Fam Med. 2002;34:584-591.

40. Institute of Medicine. Committee on Quality of Health Care in America. Crossing the Quality Chasm. A New Health System for the 21st Century. Washington, DC: National Academy Press; 2001.

41. Green LA, Fryer GE, Jr. Family practice in the United States: position and prospects. Acad Med. 2002;77:781-789.

42. Stevens RA. The Americanization of family medicine: contradictions, challenges, and change, 1969-2000. Fam Med. 2001;33:232-243.

43. McWhorter JH. Losing the Race. Self-Sabotage in Black America. New York, NY: Simon \& Schuster; 2000.

44. Future of Family Medicine Web site. Available at http:// www.futurefamilymed.org. Accessed April 14, 2003.

45. Ambulatory Health Care Data: National Ambulatory Medical Care Survey (NAMCS). Hyattsville, Md: National Center for Health Statistics. US Public Health Service; 2002. Available at: http:// www.cdc.gov/nchs/about/major/ahcd/ahcd1.htm.
46. Mundinger MO, Kane RL, Lentz ER, et al. Primary care outcomes in patients treated by nurse practitioners or physicians: a randomized trial. JAMA. 2000;283:59-68.

47. Alpert JJ, Charney E. The Education of Physicians for Primary Care. Washington, DC: United States Department of Health, Education, and Welfare; 1973. Publication HRA 74-3113.

48. Peabody FW. The care of the patient. JAMA. 1927;88:877-882.

49. Halpern J. From Detached Concern to Empathy: Humanizing Medical Practice. New York, NY: Oxford University Press; 2001.

50. Pellegrino ED. The family of medicine, broken or extended? The need for moral cement. J Fam Pract. 1984;19:287-290.

51. The Medical Education Group. The Medical Profession: Enduring Values and New Challenges. Conference Proceedings, February 25-27, 1987. Chicago, Ill: American Medical Association; 1988.

52. McWhinney IR. Family medicine in perspective. N Eng J Med. 1975;293:176-181.

53. McWhinney IR. Teaching the principles of family medicine. Can Fam Physician. 1981;27:801-804.

54. Saultz JW. Textbook of Family Medicine. New York, NY: McGraw-Hill; 2000: chaps 1-7.

55. Payer L. Medicine and Culture. New York, NY: Penguin Books; 1989.

56. Cassell EJ. Doctoring. The Nature of Primary Care Medicine. New York, NY, Oxford University Press; 1997.

57. White KL. Fundamental research at primary care level. Lancet. 2000;355:1904-1906.

58. Nutting PA, Green LA. Practice-based research networks: reuniting practice and research around the problems most of the people have most of the time. J Fam Pract. 1994;38:335-336.

59. Slawson DC, Shaughnessy AF. Becoming an information master: using POEMs to change practice with confidence. Patient-oriented evidence that matters. J Fam Pract. 2000;49:63-67.

60. Wennberg JE. Unwarranted variation in healthcare delivery: implications for academic medical centers. BMJ. 2002;325:961-964.

61. Aluise JJ. The Physician as Manager. Bowie, Md: Charles Press; 1980.

62. Schooley S. Family physicians in management. In: Saultz JW. Textbook of Family Medicine. New York, NY: McGraw-Hill; 2000:chap 58.

63. Bates DW, Ebell M, Botlieb E, Zapp J, Mullins HC. A proposal for electronic medical records in United States primary care. J Am Med Inform Assoc. 2003;10:1-10.

64. Frey JJ, Saultz JW. Academic family medicine. In: Saultz JW. Textbook of Family Medicine. New York, NY: McGraw-Hill; 2000:chap 57.

65. McWhinney IR. The importance of being different. Brit J Gen Pract. 1996;46:433-436.

66. Coulter A. Patients' views of the good doctor. Doctors have to earn patients' trust. BMJ. 2002;325:668-669.

67. Main DS, Tressler C, Staudenmaier A, Nearing KA, Westfall JM, Silverstein M. Patient perspectives on the doctor of the future. Fam Med. 2002;34:251-257.

68. Lawrence DM. My mother and the medical care ad-hoc-racy. Health Aff (Millwood). 2003;22:238-242.

69. Morgenstern L. Will the real doctor please stand up? JAMA. 2003;289:18.

70. Druss B, Marcus SC, Olfson M, Tanielian MA, Pincus HA. Trends in care by nonphysician clinicians in the United States. $N$ Engl J Med. 2003;348:130-137.

71. Institute for Healthcare Improvement. QualityHealthcare.org Web site. Available at http://www.QualityHealthCare.org.

72. American Hospital Association Commission on Workforce for Hospitals and Health System. In Our Hands: How Hospital Leaders Can Build a Thriving Workforce. Chicago, Ill: American Hospital Association; 2002.

73. Crane SC. Trends in care by nonphysician clinicians. N Engl J Med. 2003;348:1603-1604. 
74. Lurie N. The public health infrastructure: Rebuild or redesign? Health Aff (Millwood). 2002;21:28-30.

75. First Consulting Group. California Health Foundation Achieving tangible IT benefits in small physician practices. 2002. Available at http: //www.chcf.org/topics. Accessed May 5, 2003.

76. Lindberg W. Consumer Representation in Health Services Delivery. Consumers and guidelines: how to involve consumers in the development of best-practice guidelines. Healthcare Review Online. 1999;3. Available at http://www.enigma.co.nz/hcro. Accessed May 5, 2003.

77. Berwick DM. Disseminating innovation in health care. JAMA. 2003;289:1969-1975

78. White KL. The Task of Medicine. Dialogue at Wickenburg. Menlo Park, California: The Henry J. Kaiser Family Foundation; 1988.

\section{Other Sources}

Belluck P. Doctors' new practices offer deluxe service for deluxe fee. New York Times. January 15, 2002.

Berland LF, Brooks L, Westbrook PH. Baby boomers make cosmetic dentistry boom. Dent Today. 1998;17:50-52,54-55.

Berwick D, Kilo C. Idealized design of clinical office practice: an interview with Don Berwick and Charles Kilo at the Institute for Healthcare Improvement. Manag Care Q. 1999;7:1-8.

Blumenthal D. Doctors in a wired world: Can professionalism survive connectivity? Milbank Q. 2002;80:525-546.

Bodenheimer T, Wagner EH, Grumbach K. Improving primary care for patients with chronic illness. JAMA. 2002;288:1775-1779.

Bodenheimer T, Wagner EH, Grumbach K. Improving primary care for patients with chronic illness: the chronic care model, Part 2. JAMA. 2002;288:1909-1914.

Bodenheimer T. Innovations in primary care in the United States. BMJ. 2003;326:796-798.

Brown M. The HealthMed Retrievers: Profiles of Consumers Using Online Health and Medical Information. New York, NY: Cyber Dialogue; 1998.

Callahan D. Setting Limits: Medical Goals in an Aging Society. New York, NY: Simon \& Schuster; 1987.

Christianson JB, Parente ST, Taylor R. Defined-contribution health insurance products: development and prospects. Health Aff (Millwood). 2002;21:49-64.

Clancy CM, Brody H. Managed care: Jekyll or Hyde? JAMA. 1995;273: 338-339.

Cleveland $\mathrm{H}$. Coming soon: the nobody-in-charge society. The Futurist. 2000;52-56.

Cooper DJ, Rebitzer JB. Physician incentives in managed care organizations. Medical practice norms and the quality of care. The Levey Economic Institute of Bard College. Annandale-on-Hudson, New York. Public Policy Brief No 70, 2002.

Davis K, Schoenbaum SC, Collins KS, Tenney K, Hughes DL, Audet A-MJ. Room for improvement: Patients report on the quality of their health care. Commonwealth Fund; 2002.

Eddy DM. Clinical decision making: from theory to practice. Rationing resources while improving quality. How to get more for less. JAMA. 1994;272:817-824

Epstein RM, Bornell F, Visser A. Hearing voices: patient-centered care with diverse populations. Patient Educ Couns. 2002;48:1-3.

Frankel S. Health needs, health-care requirements, and the myth of infinite demand. Lancet. 1991:53-54.

Frary TN, Fleming DK, Kemle K, Segal-Gidu F, Simon B. Health care for a legion of aging baby boomers. JAAPA. 2000;13:23-24,27-28,31.

Fryer GE, Green LA, Dovey SM, Yawn BP, Phillips RL, Lanier D. Variation in the ecology of medical care. Ann Fam Med. 2003;1:81-89.
Fuchs VR. Who Shall Live: Health, Economics, and Social Choice. New York, NY: Basic Books; 1974.

Ginsburg PB. Payment and the future of primary care. Ann Int Med. 2003; 138:233-234

Grumbach K, Selby JF, Dambert CT, et al. Resolving the gatekeeper conundrum: what patients value in primary care and referrals to specialists. JAMA. 1999;282:261-266.

Knickman JR, Snell EK. The 2030 problem: caring for aging baby boomers. Health Serv Res. 2002;37:849-884

Kuupat E, Bell RQ, Kravitz RL, Thom D, Azari R. When physicians and patients think alike: patient-centered beliefs and their impact on satisfaction and trust. J Fam Pract. 2001;50:1057-1062.

Lippman H. Practice in the twenty-first century. Hipprocates. 2000:38-43.

Macready N. Baby boomers fuel demand for more plastic surgeons. OR Manager. 1997; 13:20-21

Main DS, Tressler C, Staudenmaier A, Nearing KA, Westfall JM, Silverstein M. Patient perspectives on the doctor of the future. Fam Med. 2002;34: 251-257.

Majeed A, Gray J, Ambler G, Carroll K, Bindman AB. Association between practice size and quality of care of patients with ischemic heart disease; cross sectional study. BMJ. 2003;326:371-372

Masys DR. Effects of current and future information technologies on the health care workforce. Health Aff (Millwood). 2002;21:33-41.

Miller $\mathrm{L}$. The ongoing growth of defined contribution and individual account plans: issues and implications. EBRI Issue Brief. 2002;1126-1128,31-34.

Murray M, Tantau C. Same-day appointments: exploding the access paradigm. Fam Pract Manage. 2000;7:45-50.

Murry M. Reducing waits and delays in the referral process. Fam Pract Manage. 2002;9:39-42.

Murray M, Berwick DM. Advanced access. Reducing waiting and delays in primary care. JAMA. 2003;289:1035-1040.

Murray CJL, Kawabata K, Valentine N. People's experience versus people's expectations. Health Aff (Millwood). 2001;20:21-24

Nottsinger EB. Increasing quality of care and access while reducing costs through drop-in group medical appointments (DIGMAs). Group Pract J. 1999;48:12-18.

Nutting PA, ed. Community-Oriented Primary Care: From Principle to Practice. Health Resources and Services Administration Office of Primary Care Studies. Washington, DC: US Government Printing Office; 1987.

O'Neal E. Shaping American's health care professions: how the health sector will respond to "generation X." West J Med. 2002;176:139-141.

Platt FW, Gaspar DL, Coulehan JL, et al. "Tell me about yourself": the patient-centered interview. Ann Intern Med. 2001;134:1079-1085.

Pringle M, Wilson T, Grol R. Measuring "goodness" in individuals and health care systems. BMJ. 2002;325:704-707.

Scherger JF. E-mail enhanced relationships. Getting back to basics. Hippocrates. 1996;46

Scherger J. Primary care in 2010. Hippocrates. 2000;27-33

Stelman MA. The integrated summary: a documentation tool to improve patient care. Fam Pract Manage. 2003;10:33-39.

Stefferi GE. Quality medical care. A definition. JAMA. 1988;260:56-61.

Stephens GG. Family practice and social and political change. Fam Med 2001;33:248-251.

Stephens GG. Family medicine as counterculture. Fam Med. 1998;30: 629-636

Tu HT, Hargraves JL. Seeking health care information: most consumers still on the sidelines. Center for Studying Health Systems Change. Issue Brief 61, 2003

Wagner E, Austin BT, Von Korff M. Organizing chronic care for patients with chronic illness. The Milbank Q. 1996;74:4. 